\title{
The Impact of Commodity Price Risk on Firm Value - An Empirical Analysis of Corporate Commodity Price Exposures
}

\author{
Söhnke M. Bartram \\ Lancaster University, U.K.
}

\begin{abstract}
Commodity prices are more volatile than exchange rates and interest rates. Hence, a priori, commodity price risk represents a more important source of risk to corporations. This paper presents a comprehensive analysis of the economic commodity price exposure of a large sample of nonfinancial firms. The results indicate that corporations exhibit net exposures with regard to several commodity prices. Even though commodity prices are highly volatile, commodity price risk is, however, not found to be of greater importance than other financial risks. The results are consistent with few cash flows being affected by commodity price movements, and with corporate hedging of commodity price risk (JEL: G3, F4, F3).
\end{abstract}

Keywords: capital markets, commodity prices, corporate finance, derivatives, exposure, risk management.

\section{Introduction}

Most of the exposure literature focuses on the effects of unexpected changes in foreign exchange rates or (less often) interest rates on firm value. In contrast, the impact of commodity price changes on corporations is analyzed only in a few studies and for selected firms (Tufano [1998], Bilson [1994]). Indeed, commodity price exposures of large samples and for different commodity prices have not been studied

* This paper is based on my doctoral dissertation. I am indebted to Monique Donders, Gunter Dufey, Michael Frenkel, Gordon Gemmill, Peter Pope, Peter Theodossiou (the editor), Christian Wolff, participants of the Multinational Finance Society Annual Meeting 2001 as well as two anonymous referees for valuable comments and suggestions. Part of this research was conducted during a visit at the Fisher College of Business (Ohio State University). The warm hospitality and support of the Charles A. Dice Center for Research in Financial Economics as well as funding by the German Academic Exchange Service and the German National Merit Foundation during this stay is gratefully acknowledged.

(Multinational Finance Journal, 2005, vol. 9, no. 3/4, pp. 161-187)

(C) Multinational Finance Society, a nonprofit corporation. All rights reserved.

DOI: $10.17578 / 9-3 / 4-2$ 


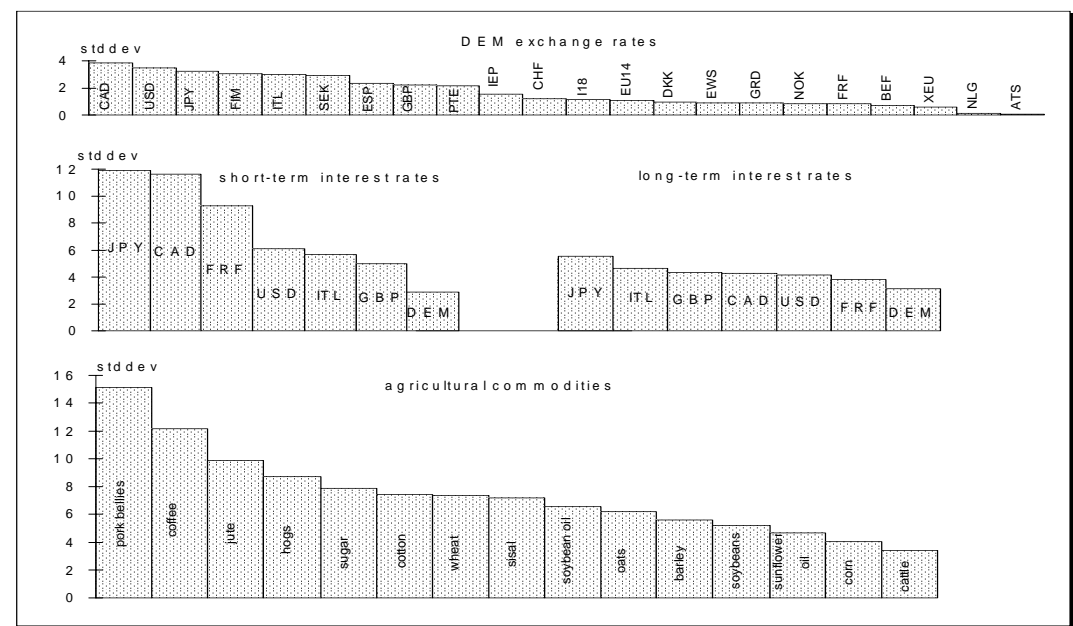

FIGURE 1. - Volatility of Financial Prices

(Continued)

to date. Commodity prices exhibit high volatility and thus represent a priori an important source of risk to nonfinancial corporations. To illustrate, Ford Motor Co. made a $\$ 1$ billion write-off of the value of its stockpile of precious metals in 2002 after prices had fallen unexpectedly (White [2002]). According to financial theory, commodity prices should affect firm value due to their impact on corporate cash flows as input and output factors of the corporate production process. This paper offers a comprehensive analysis of the effect that various commodity prices have on individual nonfinancial firms and different industries.

The focus of existing empirical exposure studies on foreign exchange rate risk has been justified with the argument that exchange rates represent a more important source of risk due to their higher volatility compared to other financial prices (Jorion [1990]). ${ }^{1}$ From a corporate perspective, it is indeed sensible to focus on the biggest risks, or at least to start risk management activities there. However, a comparison of the standard deviations of various financial prices (exchange rates, interest rates, commodity prices, stock market indices)

1. According to calculations by Jorion (1990, p. 331), the annualized volatility of the U.S. Dollar/Deutschmark exchange rate was $12 \%$ over the period 1971-87, compared to a volatility of $3 \%$ for the U.S. Treasury bill rate and $1.3 \%$ for U.S. inflation. 


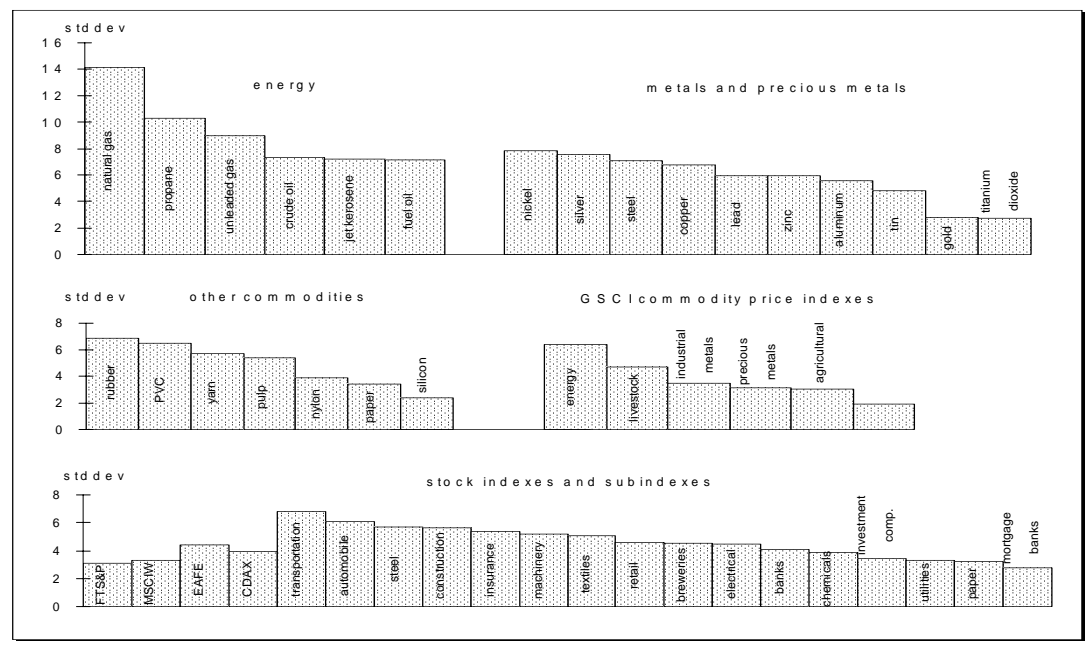

\section{FIGURE 1. - Volatility of Financial Prices}

Note: The figure shows the standard deviations of the monthly returns of various financial prices during the period 1991-95 (the values for natural gas are based on the period 12/93-12/95). I18, EU14 and EWS are indices of the currencies of 18 industrialized countries, 14 EU countries and the EWS member countries as calculated by the Bundesbank, respectively. Short-term and long-term interest rates are 3-months Eurorates and the yield of 10 -year benchmark Government bonds. Price returns are used for the calculations with commodity prices. According to results by JP Morgan, other return components of commodities (roll return and collateral return) do not affect the volatility or correlation of commodities with other financial prices (JP Morgan, 1994). Commodity price indices are based on total returns. Stock market sub-indices refer to the CDAX. CAD = Canadian Dollar, USD = U.S. Dollar, JPY = Japanese Yen, FIM = Finnish Markka, ITL = Italian Lira, SEK = Swedish Krona, ESP $=$ Spanish Peseta, GBP $=$ Pound Sterling, PTE $=$ Portuguese Escudo, IEP $=$ Irish Punt, $\mathrm{CHF}=$ Swiss Franc, DKK = Danish Krone, GRD = Greek Drachma, NOK $=$ Norwegian Krone, FRF $=$ French Franc, BEF $=$ Belgian Franc, NLG $=$ Dutch Guilder, ATS $=$ Austrian Schilling, DEM = German Mark, XEU = European Currency Unit (ECU), FTS\&P $=$ Financial Times/Standard \& Poor's, MSCIW = Morgan Stanley Capital International World Index, EAFE = Morgan Stanley Capital International index for Europe, Australia and the Far East.

shows that in recent years commodity prices exhibit even higher volatility than most foreign exchange rates and interest rates. Consequently, the impact of commodity price changes on firm value is a potentially important issue for corporate risk management.

In the light of the limited empirical evidence on the one hand, and the high volatility of commodity prices on the other hand, a systematic analysis of commodity price exposures appears warranted. In addition, hedging tools are available for many different commodity prices, providing the prerequisites for effective risk management of commodity price risk. The results in this paper emerge from a systematic and 
comprehensive study of the commodity price exposures of 490 nonfinancial corporations during the period 1987-95. As this is the first paper to estimate commodity price exposures for a large set of commodities using a large sample, it intends to motivate the relevance of commodity price risk for nonfinancial firms, based on the documented high volatility of commodity prices, and to present first empirical results to this effect. The paper analyzes the use of commodities in different industries as input and output factors, it thus derives hypotheses about the relevance of commodities in specific industries and documents the empirical effects of commodity price risk on firm value.

The results show that several sample firms are exposed to changes in commodity prices. However, while commodity prices are substantially more volatile than exchange rates and interest rates, commodity price exposures do not appear more significant overall than foreign exchange rate and interest rate exposures. There are several potential explanations for these results. While exhibiting high volatility, commodity prices may affect only few corporate cash flows, rendering the resulting effect small relative to firm size. As a consequence, commodity price risk may not be more important than other economic variables that are less volatile but that affect larger cash flows. Companies for which commodities are, however, an important part of the cost of production, are likely to manage their exposure routinely, i.e. engage in corporate hedging. Risk management activities (such as the use of derivatives and commodity price-indexed debt) with regard to commodity price risk have been documented in several industries such as gold mining (Tufano [1996], Chidambaran, Fernando, and Spindt [2001], Petersen and Thiagarajan [2000]) and oil and gas (Haushalter [2000]). In addition to derivatives use, firms may be able to manage risks by passing on costs to consumers/customers. If these risk management activities are effective, firms may largely shield themselves against commodity price risk and thus show only small residual commodity price exposures.

The remainder of the paper is organized in the following way. Section II defines the concept of commodity price exposure and reviews the existing empirical evidence. Section III presents the hypotheses and regression models, while the data set is described in section IV. Section $\mathrm{V}$ contains the empirical results, and section VI concludes. 


\section{Commodity Price Exposures}

The economic commodity price exposure describes the effect of unexpected price changes of commodities on firm value. This type of exposure has the most immediate relationship to the operative business of a firm in comparison to foreign exchange rate and interest rate exposures, since the underlying asset is a real good which may be an input or output factor in the (physical) production process of the firm. At the same time, additional, indirect effects may result from commodity price risk due to the exchange of goods and services between companies in the value chain (suppliers and customers) as well

as due to competition of firms in the same industry. In case commodity prices affect the costs and revenues of firms only to a small degree, commodity price changes can be passed on to other companies (pass-through) and/or are hedged otherwise, only a weak empirical relationship between changes in commodity prices and stock returns might be observable, though (Blake and Mahady [1991]). Consequently, one should only expect to find commodity price risk in stock prices that has not been hedged at the level of the firm. As a matter of fact, since nonfinancial firms may be expected to have expertise in the operative nature of their business including its commodity price exposures, these companies are specialized in managing commodity price risk, and effective protection against this type of risk may frequently be in place.

To illustrate, companies in the chemicals, rubber and plastic industries may on first sight be thought of to be most sensitive to oil price risk. However, these companies may also be aware of their commodity price exposure and, consequently, may hedge against oil price risk e.g. by using oil forwards and futures. While data on corporate hedging practices is hardly available for different commodities and large samples of firms, individual cases, such as MGRM, the U.S. subsidiary of Metallgesellschaft, have shown that firms in the commodity business may engage in hedging activities (Culp and Miller [1994], Culp and Miller [1995b], Edwards and Canter [1995], Mello and Parsons [1995a]). Similarly, firms in the North American gold mining industry (Petersen and Thiagarajan [2000], Tufano [1998]) and gas and oil industries (Haushalter [2000]) have been analyzed in several studies as special data sets on hedging practices are available for these industries. In addition to financial (or operative) hedging, companies may be able to pass commodity price changes on 
TABLE 1: Exchange-traded Commodities

\begin{tabular}{|c|c|c|c|}
\hline Agricultural products & & Metals & Precious metals \\
\hline$\underline{\text { Grains }}$ & Oil, Grease, Livestock & aluminum & gold \\
\hline$\overline{\text { barley }}$ & beef & antimony & palladium \\
\hline bran & broilers & bismuth & platinum \\
\hline canola & butter & brass & rhodium \\
\hline corn & cattle-feeder & cadmium & silver \\
\hline hominy feed & cheddar cheese & cobalt & \\
\hline oats & coconut oil & copper & \\
\hline rice & copra & ferro molybdenum & \\
\hline sorghum & corn oil & ferro titanium & Energy \\
\hline wheat & $\begin{array}{l}\text { cotton seed oil } \\
\text { eggs }\end{array}$ & $\begin{array}{l}\text { indium } \\
\text { lead }\end{array}$ & $\begin{array}{l}\text { butane } \\
\text { crude oil }\end{array}$ \\
\hline$\underline{\text { Food and Fiber }}$ & hams & magnesium & diesel \\
\hline burlap & lard & manganese & fuel oil \\
\hline cocoa & linseed & mercury & gas oil \\
\hline coffee & linseed oil & molybdenum oxide & gasoline \\
\hline cotton & live cattle & nickel & kerosene \\
\hline cotton seed meal & live hogs & plate & naphtha \\
\hline flaxseed & meat-bone meal & steel scrap & natural oil \\
\hline jute & milk & & propane gas \\
\hline orange juice & palm oil & tungsten ore & \\
\hline pepper & peanut butter oil & zinc & \\
\hline potatoes & pork bellies & & \\
\hline sisal & rape seed & & \\
\hline sugar & rizinus oil & & \\
\hline wool & sheep & & \\
\hline yarn & skins & & \\
\hline & soybean meal & & Other \\
\hline$\underline{\text { Other agricultural }}$ & soybean oil & & electricity \\
\hline hides & soybeans & & PVC \\
\hline paper pulp and paper & suet & & selenium \\
\hline rubber & sunflower oil & & silicon \\
\hline timber & tallow & & \\
\hline
\end{tabular}

Note: The table reports commodities that are traded on commodity exchanges as reported by The Financial Times, Wall Street Journal, Handelsblatt, UNCTAD (1994). The set of available contracts is constantly changing over time, since the trading of unsuccessful contracts ceases, and new contracts are issued.

to their customers, which may result in little or no net exposure (i.e. exposure after hedging) on their part.

While changes of all production factors or the array of products have, in principle, a direct economic bearing on the cost and/or revenue of firms, some inputs or outputs, namely commodities, are traded on the 
spot and/or futures exchanges of international financial markets. Since the emergence of commodity price derivatives such as forwards, futures and options in the 19th century, there exist exchange- and OTC-traded financial instruments that can be used to hedge changes in commodity prices. ${ }^{2}$ These traded commodities are non-precious metals (aluminum, copper, nickel, zinc, etc.), energy commodities (e.g. crude oil, natural gas, fuel oil, gas), agricultural products (such as grains, oils, grease, livestock, fibers) and precious metals (gold, silver, platinum, palladium) shown in table 1. Additional categories of commodities arise with the listing of the prices for homogeneous industrial products (e.g. semiconductors, electricity) or services (such as transportation). Via cross hedging, the price risk of many more commodities for which no contracts are traded can be hedged, if prices are highly correlated with some other commodity for which derivatives are available. ${ }^{3}$

Nevertheless, the management of commodity price risk at the corporate level has attracted very little attention to date in the academic arena. Consequently, primarily spectacular cases such as Metallgesellschaft (MGRM), which realized significant losses from transactions in the oil futures market, have been discussed in the literature. ${ }^{4}$ However, the use of financial instruments for the reduction of cash flow volatility induced by commodity price risk is becoming increasingly popular for nonfinancial firms as well.

Companies in the North American gold industry are especially well suited for the study of commodity price exposures, because they produce a homogeneous product, the exposure structure is relatively simple, a good database on risk management practices exists, and there is a liquid market for hedging instruments. Consequently, exposure studies on individual firms as well as cross-sectional analyses of firms

2. Historically, the development of (traded) futures contracts has originated in the commodities' market when grain merchants in the United States tried in 1865 to reduce the price risk associated with their inventories through contractual agreements about the future sales price; metal futures exist since 1880 (Hieronymus [1977]).

3. The most important commodity exchanges are located in Chicago (CBT, CME), New York (COMEX, CSCE, CTN, NYMEX) and London (LIFFE, IPE, LCE, LME), but also many developing countries (e.g. Brazil, the Philippines, China, India) have such an institution (UNCTAD, 1994).

4. To illustrate, the following sources deal with the case of Metallgesellschaft: Pirong (1997), Frankel and Palmer (1996), Culp and Miller (1995a), Culp and Miller (1995b), Edwards and Canter (1995), Edwards (1995), Mello and Parsons (1995a), Mello and Parsons (1995b), Sheppe (1995), Culp and Miller (1994), Falloon (1994). 
in this industry have been undertaken. The estimation of the gold price exposure of 48 companies in the North American gold industry results in more than half of the firm-quarter exposures to be statistically significant on the 5\% level (Tufano [1998]). The gold price exposure exhibits a significant negative relationship to the gold price level, gold price volatility, the degree of operative diversification and the extent of financial hedging of the firm. At the same time, there is a positive empirical relationship between the exposure and financial leverage. The analysis of the gold price exposure of the companies American Barrick and Homestake Mining shows that financial and operative hedging as well as financial and operative leverage have an impact on the exposure of firm value with regard to the analyzed risk factors (Petersen and Thiagarajan [2000]).

The existing empirical evidence with regard to commodity price exposures includes a study of the impact of oil price changes on 25 U.S. oil companies, $52 \%$ of which have a significant oil price exposure at the 5\% significance level (Strong [1991]). American Airlines exhibits a significant exposure with regard to the price of oil in several regression specifications as well (Bilson [1994]). The Swedish automobile manufacturer Volvo Cars, however, is not significantly affected by changes in the price of oil or non-energy commodities (Oxelheim and Wihlborg [1995]).

\section{Hypotheses and Regression Models}

The effect of unexpected commodity price changes on the value of corporations is primarily determined by their economic business activity (see table 2). The economic relevance of changes in commodity prices is most easily identified for companies that mine or otherwise produce a commodity, so that their sales prices or quantities are directly influenced by commodity price changes. To illustrate, this relationship exists for the agriculture/forestry industry with regard to agricultural commodities, for mining firms with regard to non-precious and precious metals as well as energy products, and for the oil-refining industry regarding rubber and other oil-based products (Sheppe [1995], Brady and Olivier [1994], Buchanan [1994]).

By the same token, industries should be affected by commodity price risk if commodities represent significant input factors of production and, consequently, the cost of raw materials is directly influenced by changes 
in prices of the commodities used. Non-precious metals are, thus, of particular importance for the primary metal and fabricated metal products industries, but also for industrial machinery/equipment and electrical/electronic equipment. Energy products are primarily relevant for the power, oil/refining, rubber/plastics, and transportation industries. Precious metals are predominantly used in the jewelry industry, while agricultural products are employed in the food, leather, textile/apparel, paper/publishing/printing and rubber/plastics industries (Wolfson and Emanuelsson [1997], Gillman and Crino [1995]).

Additional indirect effects of commodity price movements result from the economic interdependence of companies in the economic value chain (e.g. impact on competitiveness, pass-through of commodity price changes to customers). Corporations can reduce such indirect commodity price exposures by hedging the commodity price risk of their suppliers and customers. To illustrate, firms with important export activity into developing countries whose economies depend strongly on the cultivation of few agricultural commodities, can hedge fluctuations in demand via futures contracts on the major agricultural products of these countries. Similarly, chemical companies can reduce the sensitivity of their sales of pesticides vis-à-vis the economic uncertainties of the agricultural sector.

Companies in the industrial machinery and equipment sector use futures contracts on metals like aluminum, nickel or copper and sometimes on energy products, rubber or steel scrap to hedge their commodity price risk. Nuclear power plants can use oil futures to hedge against oil price-induced competitive advantages of their competitors who operate with fossil fuels (Grant [1996]). Changes in fuel prices have an impact on the transportation industry and, thus, on hotels. Therefore, hotels may hedge against oil or gas price fluctuations. Since indirect exposures are hard to quantify and since they can sometimes be reduced by cross hedging only, they appear difficult to eliminate completely (Kolb [1991]).

Apart from the use of traded derivatives, OTC contracts such as swaps, forwards or more complex financial products can be used to hedge commodity price risk (Wolfson and Emanuelsson [1997], Brady [1994]). To illustrate, it is possible to issue bonds whose face value as well as coupon payments are linked to a specific commodity price, such as gold, silver, crude oil or less often aluminum, copper, nickel, coffee, cacao (Brady and Olivier [1994], Priovolos and Duncan [1991]). These innovative ways of debt financing have the advantage that changes in 


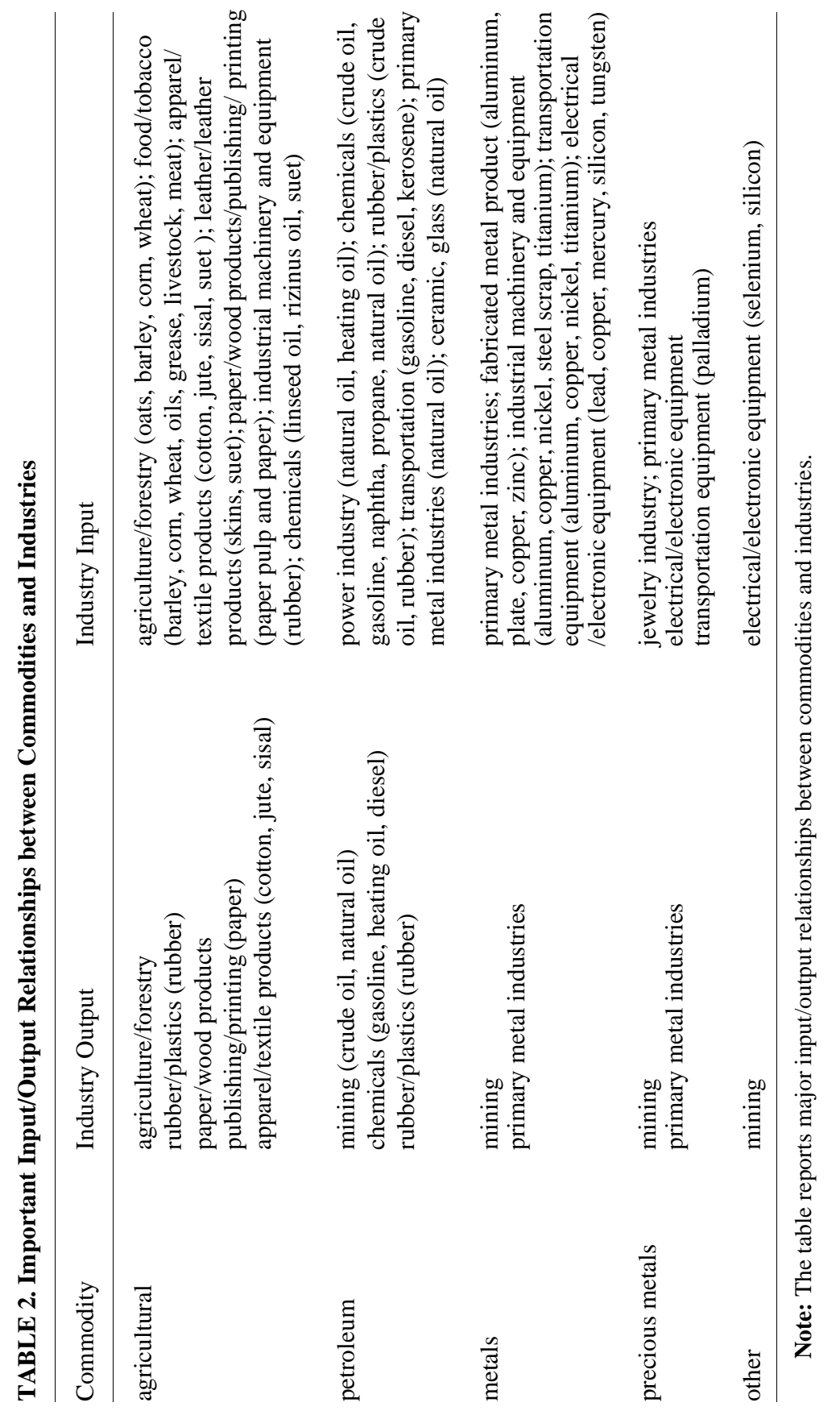


operating cash flows and interest rate payments are coordinated sensibly. Companies for whom the commodity represents a sales product thus realize high (low) interest payments when commodity prices are high (low), so that the fluctuations of both flow variables (partially) compensate each other. In the same vein, firms who use a commodity as an input factor can use commodity-indexed bonds such that high (low) input costs occur simultaneously with small (large) interest payments (Culp, Furbush and Kavanagh [1994]).

For the empirical analysis, it is assumed that commodity price exposures can be identified empirically in a particular industry at best as a result of major input/output relationships of commodities (e.g. oil price exposures in the chemical and plastics/rubber industry, or paper price exposures in the paper/publishing/printing industry). With regard to these direct commodity price exposures, agricultural products, energy products and non-precious metals commodities are predominantly relevant for nonfinancial corporations. In general, the relevance of a commodity as an input factor should induce a negative commodity price exposure, while its use as an output factor should lead to a positive exposure (see table 3). Based on the above discussion, the hypothesis will be tested that commodity price risk that has not been hedged may negatively (positively) affect share prices of corporations in industries for which a certain commodity represents an important input (output) factor in the production process. While the estimated exposure is net of corporate hedging, detailed data on corporate hedging practices is not available for the sample firms.

The analysis of the impact of commodity price changes on firm value will be based on regressions with individual commodities such as oil, copper or wheat. As there exists a large number of different commodities and as the prices of commodities of the same category can be expected to be highly correlated (e.g. crude oil, gas, fuel oil), the use of commodity price indices appears to be sensible as well. Commodity price exposures are generally assessed in the literature (Petersen and Thiagarajan [2000], Tufano [1998], Strong [1991]) with the following regression model using OLS:

$$
R_{j t}=\alpha_{j}+\beta_{1} R_{M t}+\chi_{j} R_{C t}+\varepsilon_{j t},
$$

where $R_{j t}$ represents the monthly stock return of company $j$ in period $t$, $R_{M t}$ the return on the capital market index $M$ in period $t$ and $R_{C t}$ the percentage change in commodity price (index) $C$ in period $t$. While it is 
TABLE 3. Hypotheses on Commodity Price Exposures by Industry

\begin{tabular}{|c|c|}
\hline Industry & Exposure hypotheses \\
\hline Agriculture/forestry & wheat $(+/-)$, barley $(+/-)$, oats $(+/-)$, cattle $(+)$, hogs $(+)$ \\
\hline Public utilities/mining & crude oil (-), natural oil (-) \\
\hline Chemicals & gasoline $(+/-)$, heating oil $(+/-)$, diesel $(+/-)$ \\
\hline Rubber/plastics & rubber $(+)$, crude oil $(-)$ \\
\hline Primary metal & $\begin{array}{l}\text { aluminum }(-) \text {, copper }(-) \text {, zinc }(-) \text {, lead }(-) \text {, nickel }(-) \text {, } \\
\text { tin }(-)\end{array}$ \\
\hline Industrial machinery & aluminum $(-)$, copper $(-)$, titanium $(-)$, rubber $(-)$ \\
\hline Transp. equipment & $\begin{array}{l}\text { aluminum }(-) \text {, copper }(-) \text {, transportation equipment }(-) \text {, } \\
\text { titanium }(-)\end{array}$ \\
\hline Elect. equipment & $\begin{array}{l}\text { lead }(-) \text {, copper }(-) \text {, mercury }(-) \text {, silicon }(-) \text {, selenium }(-) \text {, } \\
\text { tungsten }(-)\end{array}$ \\
\hline Misc. manufacturing & aluminum $(-)$, plate $(-)$, copper $(-)$, zinc $(-)$ \\
\hline Paper/publishing & paper pulp $(-)$, paper $(+/-)$ \\
\hline Textile/leather & cotton $(+/-)$, jute $(+/-)$ \\
\hline Food/tobacco & barley $(-)$, wheat $(-)$, coffee $(-)$, sugar $(-)$ \\
\hline
\end{tabular}

Note: The table reports exposure hypotheses for different industry sectors based on major input/output relationships of various commodities. The signs in brackets indicate the expected direction of the exposure (+: positive, $+/-$ :unclear direction, -: negative).

the unexpected innovations in commodity prices that are relevant, it is common practice to use the change in the commodity price as regressor to proxy for commodity price risk (Petersen and Thiagarajan [2000], Tufano [1998]). The market index serves the purpose of a control variable for all other systematic effects impacting stock prices. The coefficient in front of the commodity price variable is interpreted as the commodity price exposure (net of existing hedging).

Note that the risk management literature generally distinguishes between the sensitivity of firm value towards financial risks (financial exposures) and the pricing of risk factors in financial markets. To illustrate, a comprehensive literature starting with seminal work by Jorion (1990), studies the foreign exchange rate exposure of nonfinancial firms (Griffin and Stulz [2001], Williamson [2001], He and $\mathrm{Ng}$ [1998], Bartov and Bodnar [1994]). As in equation 1, these are time-series regressions by firm that assess the sensitivity of stock returns to a risk factor (changes in exchange rates) in the presence of control variables (such as the market index). In addition, there are studies that investigate whether exchange rate risk can be diversified across firms, and thus whether foreign exchange rate risk is priced in financial markets and rewarded with a risk premium in the cross-section 
of stock returns (Dukas, Fatemi and Tavakkol [1996], Choi, Elyasiani and Kopecky [1992], Jorion [1991]), more recently with conditional models that allow for time-variation in risk premia (e.g. Santis and Gerard [1998], Dumas and Solnik [1995]). Similar observations can be made with regard to interest rate exposures (e.g. Bartram [2001], Choi and Elyasiani [1997], Madura and Zarruk [1995], Martin and Keown, [1995], Sweeney and Warga [1986], Lynge and Zumwalt [1980]) and the pricing of interest rate risk (e.g. Elyasiani and Mansur [1998], Flannery, Hameed, and Harjes [1997]). By the same token, this paper also aims to analyze the commodity price exposure and not the pricing of commodity price risk.

\section{Sample Selection and Data Description}

The empirical analysis comprises the sample period 1987-1995, divided into three consecutive 3-year periods. In addition, regressions are estimated over 4- and 5-year periods as well. As the exposure may be changing over time, shorter rather than longer estimation periods are favored. All German companies are selected that were actively traded in at least one of the sub-periods on one of the eight German stock exchanges with data available on Datastream International. ${ }^{5}$ Companies are excluded for sub-periods in which they filed for bankruptcy, were acquired or exhibited a structural change in their business activity. As a result, a total of 490 nonfinancial corporations represent the sample for the empirical analysis. Based on their core business activity, all firms are classified into 20 industry classes taking into account changes in business focus over time (see table 4).

The broadest, value-weighted stock market performance index for Germany is the CDAX, which is obtained from the German stock exchange (Deutsche Börse AG). The CDAX as well as the stock price series account for dividend payments, stock splits etc. Prices of individual commodities and of five Goldman Sachs commodity price indices (GSCI) are provided by Datastream International. The indices aggregate different commodities of similar type into an agricultural index (wheat, corn, soybeans, cotton, sugar, coffee, cacao), an energy index (crude oil, unleaded gas, fuel oil, natural gas), an industrial metals

5. By building samples for different periods independently, a survivorship bias is avoided. 


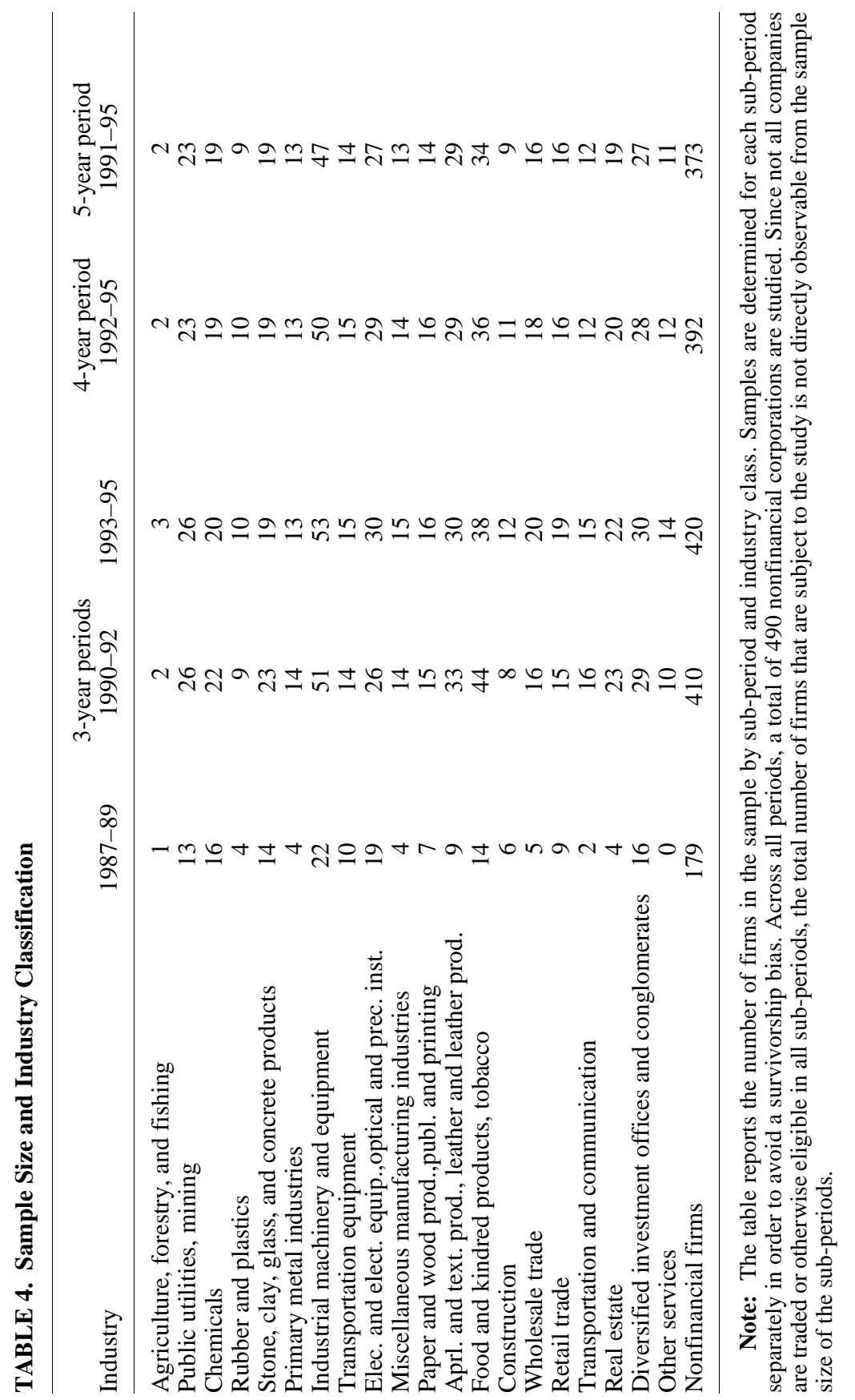


index (aluminum, copper, lead, nickel, plate, zinc), a precious metals index (gold, platinum, silver), and a livestock index (cattle, hogs). The index components are weighted by the world production of these commodities, a procedure that corresponds to value-weighting for securities. Continuously compounded monthly returns are calculated for stock prices, the market index and commodity prices.

\section{Empirical Tests and Results}

In order to analyze the commodity price exposure of the sample firms, regressions with different commodity prices or commodity price indices in addition to the CDAX as control variable are estimated. Standard errors of the coefficients are corrected for auto-correlation and heteroscedasticity using the Newey-West procedure. The results in table 5 indicate significant exposures in several cases and periods. For commodity price indices, the percentage of firms with significant exposures is in the range of 5.9\%-15.6\% (agriculture), $6.9 \%-15.1 \%$ (livestock), $8.7 \%-15.9 \%$ (industrial metals), $4.5 \%-10.7 \%$ (precious metals) and $6.1 \%-14.4 \%$ (energy) across different time periods. Similarly, $5.9 \%-15.4 \%$ of the sample firms show a crude oil exposure, while $7.5 \%-10.1 \%$ and $8.7 \%-12.8 \%$ are significantly affected by changes in the prices of copper and wheat, respectively. The results also indicate that commodity exposures have positive as well as negative signs, which are a function of the relevance of the commodity as an input/output factor and/or corporate hedging activities.

Interestingly, in spite of the fact that commodity prices are more volatile than other financial prices such as foreign exchange rates and interest rates, commodity price risk is not found to be of greater statistical importance. To illustrate, the percentage of nonfinancial firms with significant foreign exchange rate exposure is typically in the range of 5\% - 20\% (Bartram [2004], Allayannis and Ihrig [2001], He and Ng [1998], Bartov and Bodnar, [1994], Jorion [1990]), and results for interest rate exposures of nonfinancial corporations are similar (Bartram [2002]). These findings could be the result of the fact that commodity prices - though more volatile - are likely to affect only few corporate cash flows, rendering the overall economic impact of commodity price risk small relative to firm size.

Moreover, firms for which commodity price volatility is an important source of risk are likely to be aware of their exposure and 


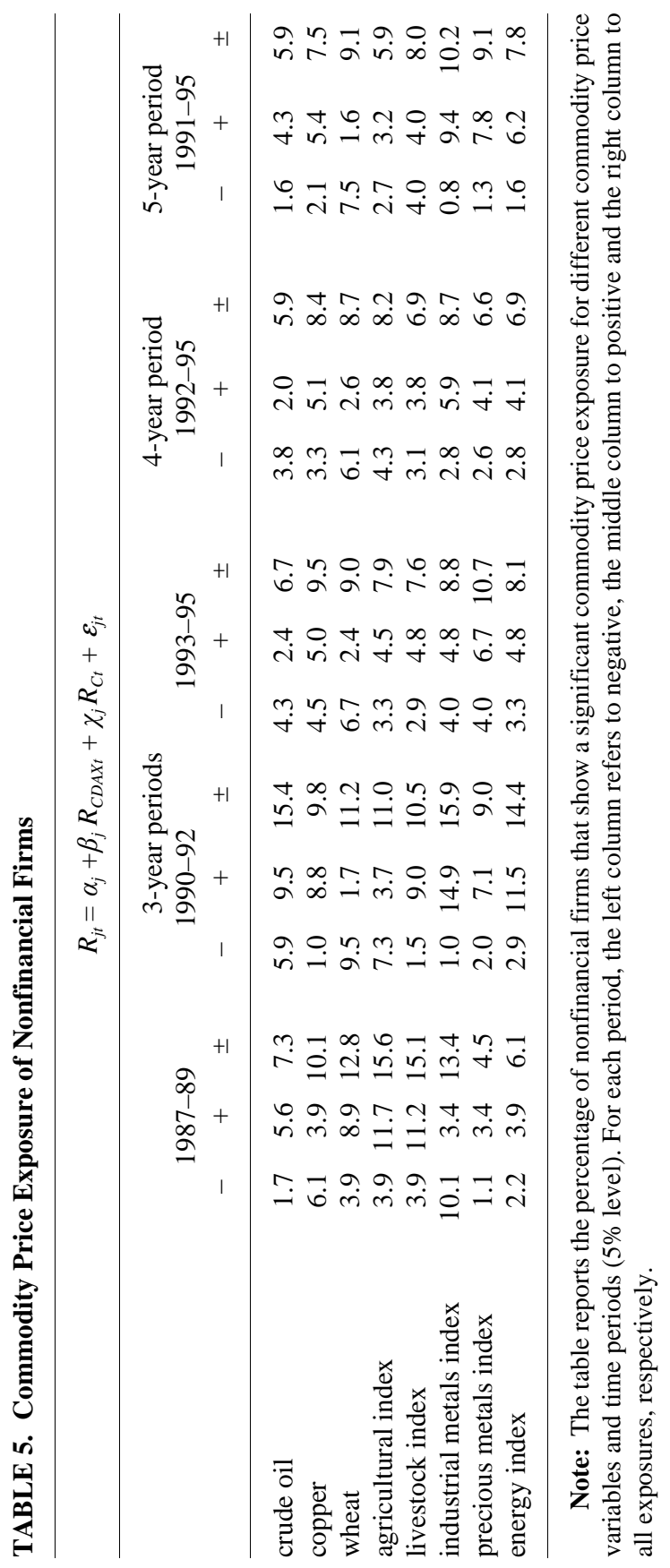


edge against commodity price risk. For instance, they may have input as well as output factors affected by commodity price changes (natural hedge) and use derivatives or commodity price-indexed debt. Recent empirical evidence of derivatives use by a large sample of nonfinancial firms in 48 countries around the world indicates that the use of commodity price derivatives is indeed most prevalent in a few industries where commodities can be expected to be most relevant, i.e. utilities, oil, mining, steel and chemicals (Bartram, Brown and Fehle [2003]). More detailed studies of small samples confirm the common use of derivatives in the North American gold mining industry (Tufano [1996], Brown, Crabb and Haushalter [2002]) or gas and oil industry (Haushalter [2000]). The frequent use of gold-linked debt structures has been documented particularly for the gold mining industry (Chidambaran, Fernando and Spindt [2001], Tufano [1996]).

Firms may also not show a significant commodity price exposure if they are able to pass the effect of commodity price fluctuations on to other firms with which they are linked in the value chain (suppliers, customers, etc.). The possibility of pass-through will depend on the market share of the firm and the overall competitive structure of the industry and markets in which it is doing business (see e.g. Bodnar, Dumas and Marston [2002]) on pass-through and foreign exchange rate exposure). In particular, passing on costs to customers can be feasible in markets where demand is relatively inelastic, so that the firm can raise prices without significantly lowering demand in order to increase revenue, profits and firm value. In contrast, pass-through is very limited in a perfectly competitive market (completely elastic demand curve). Firms may thus use a combination of pass-through and different hedging tools depending on their particular situation. As a result of these activities to reduce the effect of commodity price risk on firms' cash flows, net commodity price exposures (post-hedging exposures) will not always be detectible where gross exposures (i.e. pre-hedging exposures) exist. The empirical results can be interpreted to suggest that pass-through and hedging are important, and that firms are quite good at it (albeit not perfect, given that some regression coefficients are significant).

For commodity price exposures, an industry-specific effect could be expected. As a matter of fact, the modest number of firms with significant exposure for the entire sample could simply result from the fact that a large number of firms in particular industries are affected by a certain type of commodity price risk, while few if any firms in other 
TABLE 7. Oil Price Exposure by Industry

\begin{tabular}{|c|c|c|c|c|c|c|c|c|c|}
\hline \multicolumn{10}{|c|}{$R_{j t}=\alpha_{j}+\beta_{j} R_{C D A X t}+\chi_{j} R_{C t}+\varepsilon_{j t}$} \\
\hline & \multicolumn{3}{|c|}{ 1987-89 } & \multicolumn{3}{|c|}{ 1990-92 } & \multicolumn{3}{|c|}{ 1993-95 } \\
\hline & - & + & \pm & - & + & \pm & - & + & \pm \\
\hline Agriculture/forestry & 0.0 & 0.0 & 0.0 & 0.0 & 0.0 & 0.0 & 0.0 & 0.0 & 0.0 \\
\hline Pub. utilities/mining & 0.0 & 7.7 & 7.7 & 3.8 & 0.0 & 3.8 & 7.7 & 0.0 & 7.7 \\
\hline Chemicals & 0.0 & 0.0 & 0.0 & 0.0 & 4.5 & 4.5 & 0.0 & 0.0 & 0.0 \\
\hline Rubber/plastics & 0.0 & 0.0 & 0.0 & 0.0 & 0.0 & 0.0 & 0.0 & 0.0 & 0.0 \\
\hline Stone/clay/glass & 0.0 & 7.1 & 7.1 & 0.0 & 21.7 & 21.7 & 0.0 & 5.3 & 5.3 \\
\hline Primary metal & 0.0 & 25.0 & 25.0 & 14.3 & 0.0 & 14.3 & 0.0 & 7.7 & 7.7 \\
\hline Industrial machinery & 0.0 & 4.5 & 4.5 & 13.7 & 9.8 & 23.5 & 1.9 & 0.0 & 1.9 \\
\hline Transp. equipment & 0.0 & 10.0 & 10.0 & 7.1 & 0.0 & 7.1 & 6.7 & 0.0 & 6.7 \\
\hline Electr. equipment & 0.0 & 5.3 & 5.3 & 7.7 & 7.7 & 15.4 & 6.7 & 3.3 & 10.0 \\
\hline Misc. manufacturing & 0.0 & 0.0 & 0.0 & 7.1 & 7.1 & 14.3 & 20.0 & 6.7 & 26.7 \\
\hline Paper/publishing & 0.0 & 0.0 & 0.0 & 6.7 & 0.0 & 6.7 & 0.0 & 0.0 & 0.0 \\
\hline Textile/leather & 11.1 & 11.1 & 22.2 & 6.1 & 6.1 & 12.1 & 3.3 & 6.7 & 10.0 \\
\hline Food/tobacco & 0.0 & 0.0 & 0.0 & 4.5 & 13.6 & 18.2 & 7.9 & 2.6 & 10.5 \\
\hline Construction & 0.0 & 0.0 & 0.0 & 0.0 & 25.0 & 25.0 & 0.0 & 0.0 & 0.0 \\
\hline Wholesale trade & 0.0 & 0.0 & 0.0 & 12.5 & 6.2 & 18.8 & 5.0 & 0.0 & 5.0 \\
\hline Retail trade & 22.2 & 0.0 & 22.2 & 0.0 & 53.3 & 53.3 & 5.3 & 5.3 & 10.5 \\
\hline Transportation & 0.0 & 0.0 & 0.0 & 6.2 & 12.5 & 18.8 & 6.7 & 13.3 & 20.0 \\
\hline Real estate & 0.0 & 0.0 & 0.0 & 4.3 & 8.7 & 13.0 & 0.0 & 0.0 & 0.0 \\
\hline Conglomerates & 0.0 & 18.8 & 18.8 & 3.4 & 6.9 & 10.3 & 3.3 & 0.0 & 3.3 \\
\hline Other services & & & & 0.0 & 0.0 & 0.0 & 7.1 & 0.0 & 7.1 \\
\hline$a R^{2}$ & & 35.2 & & & 22.4 & & & 12.9 & \\
\hline
\end{tabular}

Note: The table reports the percentage of firms that show a significant commodity price exposure with regard to the price of crude oil for different industries and time periods (5\% level). For each period, the left column refers to negative, the middle column to positive and the right column to all exposures, respectively. $a R^{2}$ indicates the average adjusted $R^{2}$ statistic for all regressions in the period in $\%$.

industries. Consequently, the percentage of firms with significant exposure is analyzed by industry. Copper price risk is expected to affect firms in the primary metal industry, industrial machinery and equipment, transportation equipment, electrical and electronic equipment, and miscellaneous manufacturing industries. While these industry classes have exposure, copper price risk is also important for many firms with activities in the agriculture/forestry sector, and in chemicals, paper/publishing, textile/leather, real estate, and other services (see table 6).

Exposures with regard to crude oil are frequently observable in the industry sectors primary metal, miscellaneous manufacturing, textile 
TABLE 8: Commodity Price Exposure of DAX Companies

\begin{tabular}{lccccc}
\hline & \multicolumn{5}{c}{$R_{j t}=\alpha_{j}+\beta_{j} R_{C D A X t}+\chi_{j} R_{C t}+\varepsilon_{j t}$} \\
\hline & $1987-89$ & $1990-92$ & $1993-95$ & $1992-95$ & $1991-95$ \\
\hline crude oil & 15.4 & 3.8 & 0.0 & 3.8 & 3.8 \\
copper & 19.2 & 15.4 & 7.7 & 3.8 & 7.7 \\
wheat & 23.1 & 11.5 & 7.7 & 3.8 & 7.7 \\
agricultural index & 19.2 & 19.2 & 3.8 & 3.8 & 0.0 \\
livestock index & 19.2 & 19.2 & 3.8 & 0.0 & 7.7 \\
industrial metals index & 15.4 & 7.7 & 23.1 & 19.2 & 15.4 \\
precious metals index & 7.7 & 3.8 & 15.4 & 0.0 & 0.0 \\
energy index & 7.7 & 7.7 & 3.8 & 3.8 & 7.7 \\
\hline
\end{tabular}

Note: For all nonfinancial firms in the DAX, the table reports the percentage of firms that show a significant commodity price exposure for different commodity prices and periods (5\% level).

/leather, retail trade, and transportation (see table 7). For public utilities and mining companies, a significant oil price exposure can be identified in two periods. The variation across firms and industries is consistent with the fact that firms differ with regard to their management of commodity price risk and its importance for their activities. Direct commodity price exposures may overall play a small role due to the low relative importance of these commodities for costs and/or revenues, due to their relevance as both input and output factors, and due to corporate hedging activities.

In addition to the investigation of commodity price exposures for the entire sample, it is interesting to look at the exposure of the companies in the stock market index DAX, as these are the largest companies in the sample that gain most public attention. In order to make results comparable, only nonfinancial firms are considered as before. Whilst DAX companies are typically characterized by a larger percentage of firms with significant foreign exchange rate and interest rate exposure, the fraction of firms with significant commodity price exposure is overall similar for the companies in the DAX compared to the entire sample (see table 8).

Besides the statistical significance, the economic significance of commodity price risk (i.e. the size of the effect) for nonfinancial firms is important to analyze. For this purpose, the exposure coefficients for the DAX nonfinancial companies with regard to oil price risk and copper price risk are presented. Copper price changes matter empirically 
TABLE 9. Copper Price Exposure of DAX Nonfinancial Companies

\begin{tabular}{|c|c|c|c|c|c|}
\hline & \multicolumn{5}{|c|}{$R_{j t}=\alpha_{j}+\beta_{j} R_{C D A X t}+\chi_{j} R_{C t}+\varepsilon_{j t}$} \\
\hline & \multicolumn{2}{|c|}{$1987-89$} & \multicolumn{2}{|c|}{ 1990-92 } & $1993-95$ \\
\hline & $\beta_{j}$ & $\chi_{j}$ & $\beta_{j}$ & $\chi_{j}$ & $\chi_{j}$ \\
\hline BASF & $0.932 * * *$ & $0.158 * * *$ & $0.754 * * *$ & 0.043 & $1.128 * * *-0.066$ \\
\hline Bayer & $0.998 * * *$ & $0.098 * *$ & $0.653 * * *$ & -0.025 & $0.876^{* * *}-0.007$ \\
\hline Henkel & $0.622 * * *$ & 0.027 & $0.832 * * *$ & 0.143 & $1.120 * * *-0.060$ \\
\hline Hoechst & $0.831 * * *$ & $0.150 * * *$ & $0.689 * * *$ & 0.040 & $1.102 * * * \quad 0.012$ \\
\hline Schering & $1.186^{* * *}$ & -0.135 & $0.810^{* * *}$ & 0.137 & $0.892 * * *-0.146^{* *}$ \\
\hline Continental & $1.242^{* * * *}$ & -0.028 & 0.328 & -0.037 & $1.221 * * * \quad 0.163$ \\
\hline Deutsche Babcock & $0.920 * * *$ & -0.017 & $1.357 * * *$ & $0.233 * *$ & $1.548 * * * \quad 0.078$ \\
\hline Linde & $1.005 * * *$ & $-0.078 *$ & $1.103 * * *$ & -0.022 & $1.196 * * * \quad 0.109$ \\
\hline BMW & $1.287 * * *$ & -0.079 & $1.108 * * *$ & 0.130 & $1.120 * * * \quad 0.165 *$ \\
\hline Daimler Benz & $1.608 * * *$ & -0.024 & $1.145^{* * *}$ & -0.087 & $1.542 * * * \quad 0.142 *$ \\
\hline Volkswagen & $1.470 * * *$ & 0.050 & $1.254 * * *$ & 0.036 & $1.238 * * *-0.125$ \\
\hline Nixdorf & $1.044 * * *$ & 0.026 & & & \\
\hline Siemens & $1.513^{* * * *}$ & -0.091 & $1.002 * * *$ & $-0.154 * *$ & $1.143 * * *-0.017$ \\
\hline Feldmühle Nobel & $0.673^{* * *}$ & 0.086 & -0.022 & -0.024 & $0.133 \quad-0.081$ \\
\hline Karstadt & $1.115^{* * *}$ & 0.090 & $0.801 * * *$ & -0.034 & $0.942 * * *-0.140$ \\
\hline Kaufhof & $1.114 * * *$ & 0.142 & $0.980 * * *$ & 0.159 & $1.183 * * *-0.200$ \\
\hline Deutsche Lufthansa & $0.990 * * *$ & 0.045 & $0.776^{* * *}$ & -0.011 & $1.251 * * * \quad 0.132$ \\
\hline Degussa & $0.922 * * *$ & 0.059 & $0.923 * * *$ & 0.158 & $1.201 * * *-0.053$ \\
\hline MAN & $1.175^{* * * *}$ & $-0.160 * *$ & $1.184 * * *$ & 0.046 & $1.325^{* * *} \quad 0.150$ \\
\hline Mannesmann & $1.202 * * *$ & $-0.195 * *$ & $0.989 * * *$ & 0.013 & $1.570 * * * \quad 0.055$ \\
\hline Metallgesellschaft & $1.394 * * *$ & 0.076 & $1.129 * * *$ & $0.198 *$ & $1.639 * * *-0.131$ \\
\hline Preussag & $1.326 * * *$ & -0.096 & $1.417 * * *$ & 0.097 & $0.905^{* * *} \quad 0.107$ \\
\hline RWE & $0.688 * * *$ & -0.067 & $0.874 * * *$ & -0.087 & $1.031 * * *-0.003$ \\
\hline Thyssen & $0.812 * * *$ & -0.043 & $1.233 * * *$ & 0.160 & $1.512 * * * \quad 0.161 * *$ \\
\hline VEBA & $0.682 * * *$ & 0.073 & $0.869 * * *$ & $-0.240 * *$ & $0.856 * * * 0.039$ \\
\hline VIAG & $0.780 * * *$ & 0.022 & $0.752 * * *$ & $-0.178 * *$ & $1.030 * * * \quad 0.077$ \\
\hline SAP & & & $1.024 * * *$ & 0.152 & $0.283 * * *-0.196$ \\
\hline
\end{tabular}

Note: The table reports the market beta $\left(\beta_{j}\right)$ and copper price exposure $\left(\chi_{j}\right)$ coefficients of the DAX nonfinancial companies for different periods. *, ** and *** indicate the $10 \%$, $5 \%$ and $1 \%$ significance level, respectively.

for BASF, Bayer, Hoechst and Schering (chemicals), Deutsche Babcock and Linde (industrial machinery and equipment), BMW and Daimer Benz (transportation equipment), Siemens (electronics), MAN, Mannesmann, Metallgesellschaft, Thyssen, VEBA and VIAG (conglomerates, several with important metal trade business) (see table 9). In contrast, BASF, Henkel and Hoechst (chemicals), Linde (industrial machinery and equipment), Siemens (electronics), Kaufhof 
TABLE 10. Oil Price Exposure of DAX Nonfinancial Companies

\begin{tabular}{|c|c|c|c|c|c|c|}
\hline \multicolumn{7}{|c|}{$R_{j t}=\alpha_{j}+\beta_{j} R_{C D A X t}+\chi_{j} R_{C t}+\varepsilon_{j t}$} \\
\hline & \multicolumn{2}{|c|}{$1987-89$} & \multicolumn{2}{|c|}{ 1990-92 } & \multicolumn{2}{|c|}{ 1993-95 } \\
\hline & $\beta_{j}$ & $\chi_{j}$ & $\beta_{j}$ & $\chi_{j}$ & $\beta_{j}$ & $\chi_{j}$ \\
\hline BASF & $0.913 * * *$ & $0.105 *$ & $0.716^{* * *}$ & -0.037 & $1.147 * * *$ & 0.058 \\
\hline Bayer & $0.984 * * *$ & 0.039 & $0.550 * * *$ & -0.106 & $0.862 * * *$ & -0.046 \\
\hline Henkel & $0.627 * * *$ & $0.103 *$ & $0.964 * * *$ & $0.142 *$ & $1.133 * * *$ & 0.042 \\
\hline Hoechst & $0.814 * * *$ & 0.101 & $0.565 * * *$ & $-0.125^{*}$ & $1.126 * * *$ & 0.076 \\
\hline Schering & $1.200 * * *$ & -0.108 & $0.742 * * *$ & -0.063 & $0.898 * * *$ & 0.015 \\
\hline Continental & $1.248 * * *$ & 0.008 & $0.444 *$ & 0.117 & $1.192 * * *$ & -0.089 \\
\hline Deutsche Babcock & $0.922 * * *$ & -0.012 & $1.274 * * *$ & -0.074 & $1.491 * * *$ & -0.184 \\
\hline Linde & $1.033 * * *$ & $0.135^{* *}$ & $1.110 * * *$ & 0.006 & $1.200 * * *$ & 0.015 \\
\hline BMW & $1.307 * * *$ & 0.053 & $1.000 * * *$ & -0.104 & $1.091 * * *$ & -0.091 \\
\hline Daimler Benz & $1.614 * * *$ & 0.023 & $1.158 * * *$ & 0.010 & $1.516 * * *$ & -0.083 \\
\hline Volkswagen & $1.461 * * *$ & 0.001 & $1.239 * * *$ & -0.015 & $1.261 * * *$ & 0.072 \\
\hline Nixdorf & $1.036^{* * *}$ & -0.036 & & & & \\
\hline Siemens & $1.531 * * *$ & 0.018 & $0.956^{* * *}$ & $-0.054 *$ & $1.141 * * *$ & -0.004 \\
\hline Feldmühle Nobel & $0.659 * * *$ & 0.017 & 0.021 & 0.042 & 0.140 & 0.020 \\
\hline Karstadt & $1.095 * * *$ & -0.037 & $0.876^{* * * *}$ & 0.075 & $0.945 * * *$ & 0.007 \\
\hline Kaufhof & $1.106^{* * *}$ & 0.189 & $1.201 * * *$ & $0.233 * *$ & $1.196 * * *$ & 0.040 \\
\hline Deutsche Lufthansa & $0.978 * * *$ & -0.036 & $0.744 * * *$ & -0.032 & $1.262 * * *$ & 0.036 \\
\hline Degussa & $0.930 * * *$ & $0.200 * *$ & $0.870 * * *$ & -0.047 & $1.154 * * *$ & -0.154 \\
\hline MAN & $1.211 * * *$ & 0.066 & $1.201 * * *$ & 0.019 & $1.297 * * *$ & -0.089 \\
\hline Mannesmann & $1.255 * * *$ & $0.176^{*}$ & $0.956 * * *$ & -0.033 & $1.544 * * *$ & -0.083 \\
\hline Metallgesellschaft & $1.416^{* * *}$ & $0.364 * * *$ & $1.131 * * *$ & 0.011 & $1.742 * * *$ & 0.330 \\
\hline Preussag & $1.371 * * *$ & $0.276^{* *}$ & $1.453 * * *$ & 0.041 & $0.879 * * *$ & -0.081 \\
\hline RWE & $0.686^{* * *}$ & -0.144 & $0.836 * * *$ & -0.042 & $1.021 * * *$ & -0.034 \\
\hline Thyssen & $0.829 * * *$ & 0.087 & $1.221 * * *$ & -0.005 & $1.483 * * *$ & -0.092 \\
\hline VEBA & $0.664 * * *$ & -0.046 & $0.803 * * *$ & -0.078 & $0.845 * * *$ & -0.038 \\
\hline VIAG & $0.774 * * *$ & -0.025 & $0.785^{* * *}$ & 0.025 & $1.005 * * *$ & -0.080 \\
\hline SAP & & & $1.024 * * *$ & 0.008 & 0.278 & -0.022 \\
\hline
\end{tabular}

Note: The table reports the market beta $\left(\beta_{j}\right)$ and oil price exposure $\left(\chi_{j}\right)$ coefficients of the DAX nonfinancial companies for different periods. *, ** and *** indicate the $10 \%, 5 \%$ and $1 \%$ significance level, respectively.

(wholesale trade), Degussa, Mannesmann, Metallgesellschaft and Preussag (conglomerates) are significantly affected by oil price risk (see table 10). In comparison with foreign exchange and interest rate exposures, the coefficients for commodity price risk variables are typically smaller. As a consequence, residual commodity price exposures of stock returns do not seem to be economically and statistically more important than other sources of financial risks. 


\section{Conclusion}

Financial risks for nonfinancial institutions consist - broadly defined of unexpected changes in foreign exchange rates, interest rates and commodity prices. Interestingly, the commodity price exposure of corporations has been rarely investigated in the literature to date, even though most commodity prices are more volatile than exchange rates and interest rates. Commodity price changes can be expected to have an impact on firm value due to their relevance as input or output factors in the corporate production process. In addition, there may be important indirect effects on the value of firms to their shareholders resulting from the impact of commodity price changes on customers, suppliers or competitors and thus the competitive position of companies.

This paper presents a comprehensive investigation of the commodity price exposure of nonfinancial firms for a variety of commodity prices, based on the analysis of 490 nonfinancial corporations during the period of 1987-95. Overall, the percentage of firms with significant commodity price exposure is generally above the significance level of $5 \%$. In spite of the high volatility of commodity prices, the fraction of sample firms with statistically significant commodity price exposure is comparable to studies on foreign exchange rate exposure (Bartram [2004], Allayannis and Ihrig [2001], He and $\mathrm{Ng}$ [1998]) or interest rate exposure (Bartram [2002]). These findings are consistent with commodity price risk being relatively unimportant to many corporations (small effect relative to the size of total cash flows) and with commodity price risk being hedged.

If commodity price fluctuations represent an important source of risk, nonfinancial firms may routinely reduce their exposure through hedging, for instance by using derivatives or commodity price-linked debt. In addition, they may pass the effects of commodity price risk on to their customers if the competitive situation allows them to do so. Recent international evidence on financial derivatives usage indicates that the use of commodity price derivatives is concentrated particularly in a few industries such as utilities, oil, mining, steel, and chemicals (Bartram, Brown and Fehle [2003], Brown, Crabb and Haushalter [2002], Haushalter [2000]). Commodity price-indexed debt has also been shown to play an important role in the gold mining industry (Chidambaran, Fernando and Spindt [2001], Tufano [1996]). As a result, firms that are exposed even to volatile commodity prices may only show a small net exposure if they are hedging effectively. 
Using a sample of firms with information on corporate hedging, future research could study the effect of derivatives use on commodity price exposures. Moreover, it could corroborate the results on commodity price exposures by using alternative sets of control variables in the regressions. For example, the Fama and French (1992) factors and other macroeconomic variables such as changes in inflation, industrial production and term structure proxies could be used as additional or alternative regressors/control variables. By the same token, the importance of foreign exchange rate, interest rate and commodity price risk could be studied simultaneously in a regression model that includes proxies for all three types of risk in one equation. Furthermore, it would be interesting to investigate whether, and to what extent, commodity price risk constitutes a priced risk factor in the cross-section of stock returns, possibly with a time-varying risk premium.

\section{References}

Allayannis, G., and Ihrig, J. E. 2001. Exposure and markups. The Review of Financial Studies 14 (3): 805-835.

Bartov, E., and Bodnar, G. M. 1994. Firm valuation, earnings expectations, and the exchange rate exposure effect. Journal of Finance 44 (5): 1755-1785.

Bartov, E.; Bodnar, G. M.; and Kaul, A. 1996. Exchange rate variability and the riskiness of U.S. multinational firms: Evidence from the breakdown of the bretton woods system. Journal of Financial Economics 42 (1): 105-132.

Bartram, S. M. 2002. The interest rate exposure of nonfinancial corporations. European Finance Review 6 (1): 101-125.

Bartram, S. M. 2004. Linear and nonlinear foreign exchange rate exposures of German nonfinancial corporations. Journal of International Money and Finance 23 (4): 673-699.

Bartram, S. M., and Karolyi, G. A. 2006. The impact of the introduction of the euro on foreign exchange rate risk exposures. Journal of Empirical Finance 13(4-5):519-549.

Bartram, S. M.; Brown, G.; and Fehle, F. 2003. International evidence on financial derivatives usage. Lancaster University, University of North Carolina, University of South Carolina working paper.

Bilson, J. F. O. 1994. Managing economic exposure to foreign exchange risk: A case study of American airlines. In Amihud, Y., and Levich, R. M. (eds). Exchange rates and corporate performance. New York: Irwin 221-246.

Blake, M., and Mahady, N. 1991. How mid-sized companies manage risk. Journal of Applied Corporate Finance 4 (1): 59-65.

Bodnar, G. M.; Dumas, B.; and Marston, R. C. 2002. Pass-through and 
exposure. Journal of Finance 57 (1): 199-231.

Brady, S. 1994. A hedge too late. Corporate finance 110: 20-26.

Brady, S., and Olivier, C. 1994. How hedging gold risk lowers funding costs. Corporate Finance 118: 50-51.

Brown, G.; Crabb, P.; and Haushalter, D. 2002. Are firms successful at selective hedging? University of North Carolina working paper.

Buchanan, H. G. 1994. Choosing your weapons. Oil and Gas Investor September: 8-16.

Chidambaran, N. K.; Fernando, C. S.; and Spindt, P. A. 2001. Credit enhancement through financial engineering: Freeport McMoRan's gold-denominated depositary shares. Journal of Financial Economics 60: 487-528.

Choi, J. J., and Elyasiani, E. 1997. Derivative exposure and the interest rate and exchange rate risk of U.S. banks. Journal of Financial Services Research 12 (2-3): 267-286.

Choi, J. J.; Elyasiani, E.; and Kopecky, K. J. 1992. The sensitivity of bank returns to market, interest and exchange rate risk. Journal of Banking and Finance 16 (5): 983-1004.

Chowdhry, B., and Howe, J. T. B. 1999. Corporate risk management for multinational corporations: Financial and operational hedging policies. European Finance Review 2 (2): 229-246.

Culp, C. L., and Miller, M. H. 1994. Hedging a flow of commodity derivatives with futures: Lessons from Metallgesellschaft. Derivatives Quarterly 1 (1): 7-15.

Culp, C. L., and Miller, M. H. 1995a. Metallgesellschaft and the economics of synthetic storage. Journal of Applied Corporate Finance 7 (4): 62-76.

Culp, C. L., and Miller, M. H. 1995b. Hedging in the theory of corporate finance: A reply to our critics. Journal of Applied Corporate Finance 8 (1): 121-127.

Culp, C. L.; Furbush, D.; and Kavanagh, B. T. 1994. Structured debt and corporate risk management. Journal of Applied Corporate Finance 7 (3): 73-84.

Dukas, S. P.; Fatemi, A. M.; and Tavakkol, A. 1996. Foreign exchange rate exposure and the pricing of exchange rate risk. Global Finance Journal 7 (2): $169-189$.

Dumas, B., and Solnik, B. 1995. The world price of foreign exchange rate risk. Journal of Finance 50 (2): 445-479.

Edwards, F. R. 1995. Derivatives can be hazardous to your health: The case of Metallgesellschaft. Derivatives Quarterly 1: 8-17.

Edwards, F. R., and Canter, M. S. 1995. The collapse of Metallgesellschaft: Unhedgable risks, poor hedging strategy, or just bad luck? Bank of America Journal of Applied Corporate Finance 8 (1): 86-105.

Elyasiani, E., and Mansur, I. 1998. Sensitivity of the bank stock returns distribution to changes in the level and volatility of interest rate: A 
GARCH-M model. Journal of Banking and Finance 22 (5): 535-563.

Falloon, W. 1994. MG's trial by essay. Risk 7 (10): 28-32.

Fama, E. F., and French, K. R. 1992. The cross-section of expected stock returns. Journal of Finance 48 (2): 427-467.

Flannery, M. J.; Hameed, A.S.; and Harjes, R.H. 1997. Asset pricing, time-varying risk premia and interest rate risk. Journal of Banking and Finance 21 (3): 315-335.

Frankel, A. B., and Palmer, D. E. 1996. The management of financial risks at German nonfinancial firms: The case of Metallgesellschaft. International Finance Discussion Paper No. 560.

Gillman, P. N., and Crino, B. L. 1995. Effective strategies turn policies, instruments into payoffs. Corporate Cashflow 16 (9): 29-30.

Grant, P. 1996. Commodity derivatives aren't just for commodity users anymore. Global Finance 10 (8): 15-16.

Griffin, J. M., and Stulz, R. M. 2001. International competition and exchange rate shocks: A cross-country industry analysis of stock returns. Review of Financial Studies 14 (1): 215-241.

Haushalter, G. D. 2000. Financing policy, basis risk and corporate hedging: Evidence from oil and gas producers. Journal of Finance 55 (1): 107-152.

He, J., and Ng, L. K. 1998. The foreign exchange exposure of Japanese multinational corporations. Journal of Finance 53 (2): 733-753.

Hieronymus, T. A. 1977. Economics of futures trading. New York: Commodity research bureau.

Iorio, A. D., and Faff, R. 2001. The effect of intervalling on the foreign exchange exposure of Australian stock returns. Multinational Finance Journal 5 (1): 1-33.

Jorion, P. 1990. The exchange-rate exposure of U.S. Multinationals, Journal of Business 63 (3): 331-345.

Jorion, P. 1991. The pricing of exchange rate risk in the stock market. Journal of Financial and Quantitative Analysis 26 (3): 363-376.

JP Morgan. 1994. The JPMCI - A commodity benchmark. New York: J.P. Morgan.

Kolb, R. W. 1991. Understanding futures markets. 3rd ed. Miami: Kolb Publishing Company.

Koppenhaver, G. D., and Swidler, S. 1996. Corporate hedging and input price risk. Managerial and Decision Economics 17 (1): 83-92.

Lynge, M. J. Jr., and Zumwalt, K. J. 1980. An empirical study of the interest rate sensitivity of commercial bank returns: A multi-index approach. Journal of Financial and Quantitative Analysis 15 (3): 731-742.

Madura, J., and Zarruk, E. R. 1995. Bank exposure to interest rate risk: A global perspective. Journal of Financial Research 18 (1): 1-13.

Martin, J. D., and Keown, A. J. 1977. Interest rate sensitivity and portfolio risk. Journal of Financial and Quantitative Analysis 12 (6): 181-191.

Mello, A. S., and Parsons, J. E. 1995a. Maturity structure of a hedge matters: 
Lessons from the Metallgesellschaft debacle. Bank of America Journal of Applied Corporate Finance 8 (1): 106-120.

Mello, A. S., and Parsons, J. E. 1995b. Rolling the dice. Risk 8 (5): 49-50.

Oxelheim, L., and Wihlborg, C. G. 1995. Measuring macroeconomic exposure: The case of Volvo cars. European Financial Management 1 (3): 241-263.

Petersen, M. A., and Thiagarajan, S. R. 2000. Risk measurement and hedging. Financial Management 29 (4): 5-30.

Pirong, S. C. 1997. Metallgesellschaft: A prudent hedger ruined, or a wildcatter on NYMEX? Journal of Futures Markets 17 (5): 543-579.

Priovolos, T., and Duncan, R. C. 1991. Commodity risk management and finance. New York: Oxford University press.

Santis, G. de and Gerard, B. 1998. How big is the premium for currency risk? Journal of Financial Economics 49: 375-412.

Sheppe, D. 1995. Commodity derivatives. Asia Money - derivatives guide supplement. September: 40-44.

Strong, J. S. 1991. Using oil share portfolios to hedge oil price risk. Quarterly Review of Economics 31 (1): 48-63.

Stulz, R. M. 2003. Risk management and derivatives. Cincinnati: Southwestern Publishing Co.

Stulz, R. M., and Williamson, R. 1997. Identifying and quantifying exposures. In Jameson, R. (ed). Financial risk and the corporate treasury: 33-51. London: Risk Publications.

Sweeney, R. J., and Warga, A. D. 1986. The pricing of interest-rate risk: Evidence from the stock market. Journal of Finance 41 (2): 393-410.

Tufano, P. 1996. Who manages risk? An empirical examination of the risk management practices in the gold mining industry. Journal of Finance 51(4) 1097-1137.

Tufano, P. 1998. The determinants of stock price exposure: Financial engineering and the gold mining industry. Journal of Finance 53 (3): 1015-1052.

UNCTAD. 1994. A survey of commodity risk management instruments. Report by the UNCTAD secretariat, United Nations conference on trade and development.

White, G. L. 2002. A mismanaged Palladium stockpile was catalyst for Ford's write-off. Wall Street Journal February 6, 2002.

Williamson, R. 2001. Exchange rate exposure and competition: Evidence from the automotive industry. Journal of Financial Economics 59 (3): 441-475.

Wolfson, A., and Emanuelsson, J. 1997. Commodities - the risk of substance. Corporate Finance Risk Management \& Derivatives Yearbook 1997: $25-28$. 